Marketing i Zarządzanie

nr 1 (47) 2017, s. 291-299

DOI: $10.18276 / \mathrm{miz} .2017 .47-27$

ISSN: 1509-0507 | http://wnus.edu.pl/pl/miz/

\title{
Joanna Pikuła-Małachowska
}

Politechnika Częstochowska

Wydział Zarządzania

e-mail: asia.pikula@wp.pl

\section{Content marketing jako element komunikacji przedsiębiorstwa z rynkiem}

\section{Kod JEL: M3}

Słowa kluczowe: komunikacja, content marketing, przedsiębiorstwo

Streszczenie. Celem artykułu jest analiza, na podstawie krytycznego przeglądu literatury, najważniejszych zagadnień związanych z content marketingiem, który odpowiada za budowanie oryginalnych treści dotyczących działań firmy, jej towarów czy usług. Cechą charakterystyczną content marketingu jest to, że nie zawiera bezpośredniej oferty sprzedaży. Jego zadaniem jest budowanie wizerunku firmy jako eksperta w danej dziedzinie, a co za tym idzie - dostarczanie argumentów i eksponowanie korzyści związanych z jej ofertą. Dla działań tego typu zatem kluczowe jest poznanie potrzeb klientów docelowych. Z punktu widzenia działań przedsiębiorstw ważne jest poznanie istoty działań contentowych, które choć nie zawierają bezpośredniej oferty sprzedaży mają zdolność wpływania na decyzje zakupowe konsumentów.

\section{Wprowadzenie}

Właściwa komunikacja z klientami jest bardzo istotnym elementem działań przedsiębiorstwa na rynku. W sposób naturalny komunikacja kojarzy się z działaniami marketingowymi, które odpowiadają m.in. za takie obszary działań przedsiębiorstwa, jak pozyskiwanie nowych klientów, budowanie relacji, budowanie pozytywnych opinii na temat przedsiębiorstwa i jego rozwój. Pozornie 
właściwe komunikowanie się jest proste, każdy człowiek, każdego dnia komunikuje się z innymi - przekazuje informacje, otrzymuje informacje, dzieli się opiniami, komunikuje potrzeby i oczekiwania.

Z komunikacją związaną z klientami problem jest zdecydowanie bardziej złożony. W wielu przypadkach nie ma w niej miejsca na dialog, nie można tym samym niczego objaśnić, dopowiedzieć. Zatem, aby odbiorca zrozumiał komunikat w sposób właściwy, a tym samym zgodny z zamierzeniami nadawcy musi on być przemyślany i dobrze skonstruowany. Ponadto spójny dla wszystkich nośników. Kluczowa jest tu zatem treść komunikatu. Treść służy przede wszystkim przekazaniu klientowi rzetelnej i wartościowej dla niego informacji, która następnie, zgodnie z zamierzeniem przedsiębiorstwa, będzie przesłanką do podjęcia decyzji o zakupie.

Celem artykułu jest przedstawienie, na bazie krytycznego przeglądu literatury, głównych założeń content marketingu, a także wskazanie jego miejsca w polityce komunikacji.

\section{Komunikacja w działaniach marketingowych przedsiębiorstw}

Przedsiębiorstwo komunikuje się z rynkiem w celu wywołania zamierzonych reakcji ze strony kupujących. Nabywcy komunikują się z przedsiębiorstwem przez akceptację lub negację (odrzucenie) jego polityki marketingowej. W działaniach marketingowych za strefę związaną z komunikacją odpowiada promocja mix zwana również polityką komunikacji. Dzięki promocji mix możliwe jest dotarcie do potencjalnego nabywcy i poinformowanie go o walorach oferowanego produktu, a także o skali korzyści, jakie odniesie, przedkładając dany produkt nad ofertę konkurencji. Promocja mix jest narzędziem realizacji strategii marketingowej, dlatego jej kształt, zasady, formy i treści powinny wynikać właśnie ze strategii (Bielski, 2006, s. 124).

Do podstawowych funkcji polityki komunikacji należą (Pabian, 2008, s. 154):

- informacyjna - dostarcza nabywcom wiadomości mających zaznajomić ich z rynkiem; pełni ważną rolę w sferze edukacji rynkowej konsumentów,

- pobudzająca - wywołuje zamierzone postawy i zachowania nabywców,

- konkurencyjna - to zestaw pozacenowych instrumentów rywalizacji.

Ogólnie przyjęta strategia marketingowa przedsiębiorstwa stanowi podstawę dla formułowania celów promocyjnych, które rozpatruje się na dwóch płaszczyznach - ekonomicznej i psychograficznej (społecznej) (Michalski, 2007, s. 232).

Przedsiębiorstwa funkcjonujące współcześnie na rynku muszą komunikować się ze swoim otoczeniem. Problem nie leży zatem w kwestii, czy się komunikować, ale w tym - jak, kiedy, z kim i jak często. Ponadto nabywcy są aktywni, 
często sami decydują, jakie informacje chcą otrzymywać. Pojawia się więc pytanie, jak powinna być skomponowana mieszanka promocyjna, aby skutecznie dotrzeć do docelowych nabywców (Kotler, Keller, 2012, s. 509). Dobór strategii, instrumentów i form promocji powinien być dostosowany do ogólnych celów i strategii przedsiębiorstwa. Z uwagi na to, że jest to aktywny proces, powinien również dostosowywać się do reguł komunikowania - mówić do tego, do kogo należy (poprawna segmentacja rynku); mówić to, co należy; mówić tyle, ile należy; mówić wtedy i gdzie należy; mówić tak, jak należy (Bielski, 2006, s. 379). Zasady te można przełożyć również na poprawne budowanie strategii promocji, czyli warunki, jakie powinna spełniać mieszanka promocyjna. Strategia promocji może być budowana na sześciu następujących etapach (Bielski, 2006, s. 381386):

1. Identyfikacja odbiorców - powinna brać pod uwagę profil docelowego nabywcy i jego zachowania konsumpcyjne.

2. Określenie celów promocji (ekonomicznych i/lub informacyjno-nakłaniających).

3. Opracowanie projektu przekazu.

4. Dobór form promocji i kanału przekazu.

5. Określenie budżetu promocji.

6. Pomiar i ocena skuteczności promocji.

Bez promocji i związanej z nią informacji przedsiębiorstwo nie mogłoby funkcjonować na rynku. Współcześnie osoby odpowiedzialne za działania związane z komunikacją marketingową przede wszystkim zastanawiają się, co zrobić, jakie aktywności wybrać, aby komunikat skutecznie dotarł do wybranej grupy odbiorców. Jeżeli konsument nie ma informacji o firmie i jej produktach oznacza to, że nie wie o jej istnieniu i nie kupuje jej produktów. Przedsiębiorstwa wykorzystujące w swojej działalności promocję przekazują na rynek informacje o swoich działaniach, kształtują swój wizerunek oraz pobudzają sprzedaż swoich produktów. Informacja i wiedza są obecnie specyficzną kategorią produktu. Nabywcy aktywnie szukają i selekcjonują wiadomości na temat przedsiębiorstw oraz ich produktów i marek. Ponadto potrafią sami tworzyć komunikaty związane z produktami czy ich markami i skutecznie przekazywać je innym konsumentom. Zatem osoby odpowiedzialne za marketing nie tylko borykają się z wyzwaniami związanymi ze skutecznym dotarciem do odbiorcy, ale również z problemem skutecznego unikania złych opinii lub neutralizowania ich skutków w odniesieniu do działalności rynkowej.

\section{Istota content marketingu}

Rozważając temat content marketingu (marketingu treści) należy w pierwszej kolejności umiejscowić go na mapie komunikacji przedsiębiorstwa z rynkiem. Za komunikację marketingową przedsiębiorstwa $\mathrm{z}$ otoczeniem odpowiadają przede 
wszystkim elementy promocji mix (reklama, PR, promocja sprzedaży, sprzedaż osobista, marketing bezpośredni); za działania online odpowiada marketing bezpośredni, a tu właśnie główne zastosowanie znajdują działania contentowe. Bez wątpienia marketing bezpośredni nabierał znaczenia wraz ze wzrostem zainteresowania firm internetem jako miejscem, w którym/poprzez które komunikują się $\mathrm{z}$ docelowymi nabywcami. Przełomem z pewnością było pojawienie się i rozwój mediów społecznościowych. Wzrost znaczenia sieci internetowej jako miejsca kontaktu z klientami przyczynił się nie tyle do powstania pojęcia content marketingu, co do jego reaktywacji i/lub rozszerzenia zastosowania ${ }^{1}$. Bardzo często można spotkać opinie ekspertów, którzy twierdzą, że content marketing nie jest już żadną nowością. Nie jest to jednak, w opinii autorki, równoznaczne z tym, że przedsiębiorstwa nauczyły się go skutecznie używać.

Content marketing to obecnie już bez wątpienia odrębna dyscyplina działań marketingowych. Z badań Econsultancy/Outbrain Content Marketing Survey 2013 wynika, że 64\% marketerów postrzega content marketing jako jedno z najważniejszych zadań aktywności w internecie. Jednocześnie 38\% firm wypracowało strategię z nim związaną, 34\% przeznaczyło część budżetu na tę formę aktywności, a 46\% wyznaczyło pracowników odpowiedzialnych za marketing treści (Bzdyra-Maciorowska, 2014). Content marketing jest elastyczny, dzięki czemu z powodzeniem dopasowuje się do obowiązującej rzeczywistości, w której social media mają bardzo silną pozycję, jeśli brać pod uwagę komunikację $\mathrm{z}$ docelowymi nabywcami. Samo pojęcie może być zdefiniowane jako strategia marketingowa przedsiębiorstwa, której cel oparty jest na tworzeniu i dystrybuowaniu cennych, istotnych oraz spójnych treści mających przyciągnąc uwagę przejrzyście zdefiniowanych grup docelowych (Soczka, 2016).

Cechą charakterystyczną content marketingu jest to, że nie jest oparty na działaniu perswazyjnym, ale na dostarczaniu argumentów i eksponowaniu korzyści; tym samym musi wykorzystywać wnikliwą analizę potrzeb klienta ${ }^{2}$. Do najpopularniejszych form content marketingu zalicza się: artykuły i wypowiedzi eksperckie w mediach, blogi firmowe, publikacje w mediach społecznościowych, newslettery, infografiki, studium przypadku, prezentacje, e-booki, filmy informacyjne, zakładkę najczęściej zadawane pytania (FAQ), webinaria (Soczka, 2016).

Jednym z najważniejszych zadań marketingu treści jest budowanie oryginalnego i wyjątkowego przekazu, który ma zaciekawić konsumenta i zatrzymać go pod danym adresem. Właściwe budowanie strategii content marketingu jest oparte na umocnieniu pozycji przedsiębiorstwa w sieci. Niepowtarzalna treść, zrozumiała i przejrzysta, a przy tym taka, która przykuje uwagę czytelnika

\footnotetext{
${ }^{1}$ Pierwszy raz sformułowanie content marketing użył John F. Oppedahl w 1996 r. podczas spotkania American Socjety for Newspaper Editors.

${ }^{2}$ Sama treść nie jest równa marketingowi treści, działanie w tym zakresie musi być oparte na strategii.
} 
(klienta) może być bezcenna, biorąc pod uwagę szeroką ofertę konkurencji. Praca nad marketingiem contentu powinna przebiegać w następujących po sobie etapach (Stawarz, 2014):

1. Określenie celu i kluczowych wskaźników. Cele powinny być związane z tożsamością firmy, jej misją i tym, jaki komunikat chce przekazać klientowi.

2. Określenie grupy docelowej. Ustalenie, z kim firma chce się komunikować: kim są kluczowi nabywcy, co lubią, gdzie bywają, czym mogą się interesować, a przede wszystkim, jakie korzyści chcą osiągnąć i jakie potrzeby zaspokoić nabywając produkt.

3. Zdefiniowanie procesu zakupowego - ma pomóc firmie uzyskać odpowiedź na pytanie, w jaki sposób klienci wchodzą w relacje z marką i jak podejmują decyzje o zakupie.

4. Określenie „Zerowego Momentu Prawdy” - to opis współczesnego modelu zakupowego. Większość konsumentów zanim podejmie decyzje o zakupie przegląda sieć w celu znalezienia różnego rodzaju informacji na temat produktu. Pokazanie się konsumentowi na tym etapie i przyciągnięcie jego uwagi przez intrygującą, ciekawą czy przejrzystą treść to często klucz do późniejszego sukcesu sprzedażowego.

5. Tworzenie kalendarza redakcyjnego, na który składają się: plan treści plus narzędzia content marketingu, wybrane kanały, w jakich treści zostaną opublikowane oraz sposoby promocji treści.

6. Realizacja i pomiar.

Internet daje olbrzymie możliwości zarówno użytkownikom, jak i firmom. W sieci strefy firm i konsumenta mają szansę się przenikać i uczyć od siebie nawzajem. Wśród korzyści wynikających z zastosowania strategii contentowej najczęściej wymienia się: zwiększenie sprzedaży, wsparcie dla SEO, generowanie leadów, budowę wizerunku firmy jako eksperta w danej dziedzinie, zwiększenie rozpoznawalności marki (Soczka, 2016).

W literaturze związanej przede wszystkim z praktyką marketingu można znaleźć wiele nawiązań do tego, w jaki sposób słowa mogą sprzedawać, a zatem jaką wartość mogą mieć dla przedsiębiorstwa. Odnosi się to m.in. do siedmiu słów, które mogą skutecznie zachęcić do kupna dobra/usługi (Skowerski, 2017):

1. Ty/ja - w znaczeniu klient jest najważniejszy dla marki, a marka dla niego (jesteśmy dla siebie najważniejsi).

2. Liczby - to co jest komunikowane i zapamiętywane ma wartość.

3. Odkryj (w miejsce sprawdź/zobacz) - klienci chcą być odkrywcami.

4. Udowodniony - klienci nie chcą, aby na nich testowano dobro/usługę.

5. Bezpieczny, np. komunikacji produktów aptecznych i motoryzacyjnych.

6. Nowy/innowacyjny - w sensie wyjątkowy.

7. Seks/miłość, bo to (podobno) sprzedaje wszystko. 
Budowa treści to też umiejętność snucia ciekawej opowieści. Przykładem jest eksperyment o nazwie „Znaczące przedmioty” zorganizowany przez Roba Walkera oraz Josha Glenna. Eksperyment ten miał charakter pseudonaukowy (mierzalny), a jego celem było określenie wartości opowieści. Obaj panowie na tzw. pchlich targach kupili dwieście przypadkowych i pozbawionych jakiegokolwiek znaczenia przedmiotów. Średnia cena zakupu to 1,25 dolara. W grupie zakupionych produktów znalazły się takie przedmioty jak: świnka - skarbonka, figurka z lodowych patyków, popielniczka z wizerunkiem jastrzębia czy piłka do golfa. Następnie poproszono ludzi, którzy zawodowo zajmują się pisaniem o stworzenie krótkich historii do każdego przedmiotu. Żadna z nich nie miała być prawdziwa. Dzięki temu zabiegowi piłka do golfa była tą, którą kiedyś rzucono w twarz pewnemu senatorowi podczas konferencji prasowej. Dalej historia nawiązywała do tego, że przepisy mówiące o tym, że dziennikarzom nie wolno na konferencje prasowe w amerykańskim Senacie wnosić golfowych piłek, wzięły początek właśnie od tej konkretnej. Popielniczka z jastrzębiem natomiast była prezentem od kolegów z NASA po zakończeniu prac nad nowym rodzajem broni. W ten sposób „przygotowane” produkty twórcy eksperymentu wystawili na aukcję e-bay. Jaki osiągnięto efekt? Na inwestycji wynoszącej ok. 250 dolarów zarobili 8 tys. dolarów $-3200 \%$ ROI. To pokazuje jak ważna jest historia o produkcie, która czyni z niego coś wyjątkowego (Tkaczyk, 2014).

\section{Content marketing a konsumenci}

Jak zostało wcześniej wspomniano content marketing ściśle związany jest z zarządzaniem działalnością promocyjną przedsiębiorstwa w internecie. Srodowisko internetowe jako miejsce prowadzenia działań związanych z komunikacją pod względem ogólnych założeń i zadań jest dość podobne do mediów tradycyjnych, określa się tu takie zmienne jak (Łopaciński, 2015, s. 14):

- adresaci działań,

- cel działań,

- treść komunikatu,

- termin działań,

- sposób dotarcia do odbiorców,

- budżet działań,

- sposób oceny rezultatów.

Jeśli przyjmie się, że content marketing odnosi się przede wszystkim do działań przedsiębiorstw w sieci internetowej, to warto zastanowić się nad sylwetką współczesnego konsumenta i jego aktywnością w sieci. Wiek XXI uznawany jest bowiem za czas narodzin e-konsumenta. Zmiany związane z rewolucją informatyczną, rozwojem telefonii komórkowej i internetu dokonały się właściwie błyskawicznie, bo w czasie życia zaledwie jednego pokolenia (Jaciow, Wolny, 2011, s. 9). 
Do cech charakterystycznych dla e-konsumenta zalicza się (Jaciow, Wolny, 2011, s. 12-13):

a) cenienie wygody: dokonywanie zakupów, płacenie rachunków itp. o każdej porze dnia; również otrzymywanie zamówionych produktów w oznaczonym miejscu i oznaczonym czasie;

b) brak anonimowości: przekłada się to na indywidualne traktowanie i odczucie bycia ważnym (w sieci odbywa się to przez przywitanie użytkownika, zwracanie się do niego po imieniu przy kolejnych zakupach, pytaniach);

c) cenienie czasu: pełna samoobsługa przy zakupach internetowych pozwala kontrolować takie czynności, jak: poszukiwanie informacji, złożenie zamówienia, śledzenie przesyłki, sprawdzanie konta, zadawanie pytań 24 h na dobę;

d) cenienie wartości: szuka lepszej oferty, oczywiście identycznie jak konsument „tradycyjny” tyle, że e-konsument jednym „kliknięciem” w ułamku sekundy przenosi się do konkurencji;

e) zgoda na wyższą cenę: za bezpieczeństwo transakcji, pewność dostarczenia przesyłki, skrócenie czasu dostarczenia przesyłki;

f) modyfikacja oferty: dostosowanie dobra/usługi do własnych preferencji.

W kontekście tematyki przedmiotowego artykułu szczególnie istotna wydaje się charakterystyka zachowań e-konsumenta związana z poszukiwaniem informacji na temat produktów. W odróżnieniu od konsumentów, którzy nie dokonują zakupów w sieci, a dla których źródła informacji stanowią: rodzina, znajomi, sprzedawcy czy reklamy, e-konsumenci kierują się informacjami pochodzącymi z oficjalnych stron internetowych sprzedawców, forów internetowych, blogów, porównywarek cenowych czy sklepów i aukcji internetowych (Jaciow, Wolny, 2011, s. 16). Tu dopiero widać rzeczywiste znaczenie content marketingu. Konsument pozostaje niejako sam na sam z treścią, do raz opublikowanej nie można już nic dodać, nic dopowiedzieć. $Z$ tego też powodu tak wiele mówi się o jakości treści i o tym, że budowa strategii contentowej jest bardzo trudnym i odpowiedzialnym zadaniem. Wymaga zaangażowania, eksperckiej pracy $i$, co z tego wynika, czasu. Odchodzi się od przekonania, że treści w sieci powinny być krótkie, ponieważ konsument ceni sobie przede wszystkim czas. Powinny być ciekawe i rzeczywiście wartościowe. Jeśli klient szuka w sieci informacji to jest naturalne, że szuka tej najbardziej rzetelnej i naturalne jest, iż poświęci na to odpowiednią ilość czasu. Wartość treści ocenia się tu głównie po tym, jak często odbiorcy dzielą się nią ze znajomymi (Święciaszek, 2016). Wzbogacenie produktu w informacje uznawane jest za formę innowacji jego wartości, charakterystyczną dla działań firmy w internecie (Doligalski, 2013, s. 81). 


\section{Podsumowanie}

Szacunkowo codziennie w internecie pojawia się $27 \mathrm{mln}$ nowych treści (Bucki, 2016). Content marketing, aby był skuteczny musi być zatem bardzo dobrze przemyślany. Obszary tematyczne powinny być tu precyzyjnie określone, z jednej strony pod kątem możliwości redakcyjnych, z drugiej oczekiwań klientów. Powinna być również tworzona dokumentacja strategii, zawierająca m.in. cele strategiczne oraz mierzalne wskaźniki sukcesu.

Treść, a co za tym idzie poprawne używanie języka, przechodzi swego rodzaju renesans. Odchodzi się bowiem od przekonania, że w sieci im krócej tym lepiej. Najważniejsze jest, aby tekst niósł z sobą wartość, a wartością jest w tym wypadku rzetelna informacja. Temu bowiem przede wszystkim służy content marketing - budowaniu rzetelnej informacji. To z kolei wpływa na postrzeganie firmy jako eksperta w danej dziedzinie; im częściej konsument szuka informacji w danym miejscu i częściej poleca stronę/treść znajomym, tym lepiej dla firmy.

\section{Bibliografia}

Bielski, I. (2006). Wspótczesny marketing. Filozofia, strategie, instrumenty. Warszawa: Wydawnictwo Studio Emka.

Bucki, P. (2016). Content marketing - trudna miłość. Marketing w Praktyce, 4, 9-10.

Bzdyra-Maciorowska, A. (2014). 10 trendów kontent marketingu. Marketing w Praktyce, 4, 74-75.

Doligalski, T. (2013). Internet w zarządzaniu wartościa klienta. Warszawa: Oficyna Wydawnicza SGH.

Jaciow, M., Wolny, R. (2011). Polski e-konsument, Typologia, zachowania. Gliwice: Wydawnictwo Helion.

Kotler, Ph., Keller, K.L. (2012). Marketing. Poznań: Wydawnictwo Rebis

Łopaciński, K. (2015). Skuteczność promocji internetowej. Warszawa: Polskie Wydawnictwo Ekonomiczne.

Michalski, E. (2007). Marketing, podręcznik akademicki. Warszawa: Wydawnictwo Naukowe PWN.

Pabian, A. (2008). Środki i formy marketingowego oddziatywania na konsumentów. Częstochowa: Wydawnictwo Politechniki Częstochowskiej.

Skowerski, S. (2017). 7 słów, które sprzedadzą wszystko. Marketing w Praktyce, 3, 34-36.

Soczka, A. (2016). 9 miesięcy z kontent marketingiem. Marketing w Praktyce, 3, 73-76.

Stawarz, B. (2014). Jak zostać strategiem kontent marketingu. Marketing w Praktyce, 10, 18-19.

Święciaszek, M. (2016). Content uwodzący wyszukiwarki, Marketing w Praktyce, 8, 17-18.

Tkaczyk, P. (2014). Ile jest warta opowieść o produkcie? Marketing w Praktyce, 9, 6-9.

\section{Content Marketing as a Modern Tool of Market Communication}

Keywords: communication, content marketing, enterprise

Summary. The objective of the paper is analysis, on the basis of critical literature review, of the most important issues related to content marketing, which is responsible for building original content concerning the actions of companies, their products or services. The characteristic feature of content marketing is the fact that it doesn't present direct sale 
offer. The purpose of the content marketing is building the company's image as an expert in the concrete field. It involves giving convincing arguments and exposing benefits of the company offer. The starting point in content marketing activity is precise recognition of target customer needs. From the enterprises' point of view it is important to recognize the essence of content actions, which, although do not contain the direct sales offer, have the ability of influence the purchasing decisions of consumers.

Translated by Anna Niedzielska

\section{Cytowanie}

Pikuła-Małachowska, J. (2017). Content marketing jako element komunikacji przedsiębiorstwa z rynkiem. Marketing $i$ Zarzadzanie, 1 (47), 291-299. DOI: 10.18276/miz.2017.47-27. 